\title{
[ Obsessive Butcher: Francis Brady's Gift and Exchange in Patrick McCabe's The Butcher Boy ]
}

\section{Christopher Koy}

University of South Bohemia,

České Budějovice

[Abstract] Patrick McCabe's novel The Butcher Boy (1992) has been critically examined from a very large number of perspectives for over a quarter of a century. Instead of a comprehensive look at the entire Irish novel or an analysis of the compelling language, psychology, or its historical context, this article will narrowly focus on Derrida's look at the ethics of gifts and exchanges and apply his notions to the nature and eventual deterioration of the close relationship between Francis (Francie) Brady and his childhood friend Joe Purcell as a contribution to an understanding about the homicidal behavior of the narrator Francis Brady.

[Keywords] Irish novel; Patrick McCabe; The Butcher Boy; Irish literature; Jacques Derrida; ethics and religion 
The novel The Butcher Boy by Patrick McCabe (1955-) has been interpreted from a variety of approaches for some two and a half decades: it has been critiqued as a neocolonial and post-colonial novel (Smith, Gauthier, and Cotti-Lowell), a novel in which a world of illusion is created by the possibly schizophrenic narrator's special language (Wallace) and as a realistic expression of the collusion between the Catholic Church and the Irish government (Molino). Tom Herron employs Jacques Derrida's metaphor of the coming episteme "a period in which the reassuring structures of belief and thought are placed in laborious interrogation" (Herron 168). Herron refers to the traditional de Valerian Irish utopia of the ideal Catholic family, cosy homes, purity and innocence, athletic youth, and sentimental Celtic ballads which are juxtaposed to McCabe's depiction of the drunken, wife-battering Irishman who heads the Brady household. This paper, however, will focus on a different means of interpretation of The Butcher Boy by applying the ethical notions of gift-giving and exchange expressed in a three works by the philosopher Jacques Derrida (1930-2004) to the novel's protagonist Francis Brady as well as other characters in the novel.

The Butcher Boy was awarded the Irish Times-Aer Lingus Prize for Fiction in 1992 and was shortlisted for the Booker Prize in Britain. In 1998 it was adapted into a film directed by Neil Jordan who won the Berlin International Film Festival Prize for best director. The screenplay was co-authored by Jordan and McCabe. At the age he wrote this remarkable novel of a traumatized childhood, McCabe, then in his mid-30s, created a frame narrative composed by an adult Francie Brady, probably sharing the same age of McCabe during the composition. Thus the narrative of looking back at childhood appears somewhat autobiographical. Likewise, as a child McCabe had been an avid comic book reader. He experienced some anxieties as a young man which he likely projected onto his lead character Francie Brady (FitzSimon 175-177). McCabe shares with Francis Brady an alcoholic musician father who died while the teenage Patrick was still attending secondary school. The experience of his traumatic homecoming to the border town Clones (in County Monaghan) was the basis of a 2008 award-winning documentary, Patrick McCabe Comes Home. These pseudo-autobiographical elements of his fiction are, as McCabe himself asseverates, about "filling in those gaps that haunt you" (Guidera n.p.). The novel has received significant sustained critical attention in the last quarter century. It has been argued that Francie Brady murdered Mrs. Nugent under the influence of a combination of monster movies, comic books and sexual abuse by a priest (Cotti-Lowell and Eldred 54-57). Applying Derrida's theorizations of the gift, however, supports a reconsideration of the novel, explicitly to illuminate the character and behavior of the protagonist Francis Brady in a new way.

Exchanges abound in The Butcher Boy, yet they have not been explored. By narrowly focusing on gift/exchange behavior, the paper will show why the protagonist Francis Brady continuously seeks an exchange as defined by Derrida (in contrast to "the gift, the impossible") in his devoted alliance and intense interactions with his closest childhood friend Joe Purcell. I will argue that the eventual loss of this friendship results in Francie's painfully psychotic reaction and his succeeding violent response. Francie reconstructs his harrowing childhood as an adult, and as the narrator unreliably describes 
the bleak family environment, he downplays difficulties with his father after his mother Annie Brady commits suicide and offers his responses as an active, though traumatized boy in a form that contains comic as well as deeply disturbing facets.

In Given Time: 1. Counterfeit Money which engages with the anthropology of Marcel Mauss, Jacques Derrida (1930-2004) argues that obligation in an exchange helps reveal the ethics of gift-giving, and later in The Gift of Death, Derrida argues for the gift's association to religious passion which motivates one's spiritual searching. Patrick McCabe's obsessively rambling protagonist in The Butcher Boy, Francis Brady, alters from a loyal, friendship-above-all young boy into an incredibly violent scatological-oriented vengeful teenager and then back to a calm, Mother Mary-encouraged wounded man who at the end earnestly reflects and longs for a life of harmony rather than of holy redemption. Derrida's ideas of the "gift" in its ethical context will be cited to convey a significant aspect of what Francie Brady is doing with his story. In a religious context, the ethical question is significant. As Crockett points out, "For Derrida, the pure possibility of religion concerns the promise, the possibility of making a promise and being responsible to and for another person. This responsibility is ethical in many respects" (14).

A neighbour of the Brady family, Mrs. Nugent becomes the antagonist and a villainous force in Francie's life by loudly and very publicly rebuking his mentally-disturbed mother, Annie Brady, and in particular Francie's drunken father as the opprobrium of the town, disgracefully calling the Brady family "pigs". Insulting the entire Brady Family comes as a consequence of Francie's behavior as provocateur towards her "nerdy" son Philip as well as the excessive drinking and chronic unemployment of Francis's father Benny Brady. Through her overbearing English manners, Mrs. Nugent endangers all that is dear to the strong-willed Francie: his already dysfunctional family and subsequently his special friendship with Joe Purcell, the latter of which I will focus on since it has not been emphasized by scholars up to now. Mrs. Nugent's haughty manners and short temper leaves her impervious to the issues that her intolerant rebuke causes in Francie's neurotic mind and eventually puts her into mortal danger.

After trading stolen comic books, Joe Purcell offers what may be designated the first "gift" of the narrative which has a profound effect on Francie Brady. A failed attempt at suicide and mental breakdown by Annie Brady results in her commitment to a mental institution. However, Joe insists to Francie that it is really like a garage where a car must go on occasion for a tune-up. That Francie's mother is only going away for a "tune-up" as Joe innocuously puts it, serves as a great consolation for Joe's friend Francie. This may be distinguished from the deep shame father Benny Brady felt. While Joe's analogy of mental illness is no physical gift, Joe endears himself with Francie in a profound way, showing stirring empathy which succeeds in comforting Francie.

This friendship is cemented outside of town and in secret. Francie and Joe regularly escape to the mountains, rivers and woods to play with intrepidity Cowboys and Indians, to fish, shoot bows and arrows, and generally be free of any worldly concerns. Yet adult concerns eventually follow them out to the isolated wild Irish countryside: Francie's mother commits suicide in the river Francie and Joe regularly swim in; afterwards, 
Mrs. Nugent sends her low-class relatives out to the same isolated river setting to physically attack Francie. As Kamila Vránková maintains regarding an isolated setting in Wuthering Heights, the "paradise-like place turns repeatedly into a trap where not only human life but also human soul can be lost. These contrasting functions of natural background correspond with extremes in the states of mind" (64). While Francie seeks escape and relief from people outside of town, he and those he loves are unknowingly placing themselves in grave danger.

In contrast to Francie's obsessive exchange behavior, he makes an effort to annoy Philip and especially his mother by avidly engaging in a fake exchange:

I was standing in the middle of the footpath. Mrs. Nugent held on to her hat with one hand and took Philip with the other would you let me by please she says.

Oh no I can't do that I said, you have to pay to get past... It was called the Pig Toll Tax. Yes, Mrs. Nugent I said, the pig toll tax it is and every time you want to get past it costs a shilling... (McCabe 11)

Rather awkwardly, Francie succeeds in intimidating Mrs. Nugent even though he does not fully replicate his theft of Philip's comic books. In demanding a pig toll tax from Mrs. Nugent, he attempts negative pay-back for her verbal abuse of his mother. Indeed, Francie derives a sense of satisfaction that he has really embarrassed her: "She got all heated up then oh yes hot and bothered" (12). Nevertheless, Francie's exchanges are complicated by the uncertainty of their reciprocity.

After the dreadful Christmas party hosting Uncle Alo (Aloysius) and a concluding hostile family argument, Francis runs away from his family home to Dublin, away from his depressed mother who had likely felt she had nothing more to live for. No one knows of Francie's whereabouts or what had happened to him. Francie's presence may well have been the only thing that had kept Annie Brady alive in her otherwise thoroughly depressing marital life. McCabe eventually places his protagonist into a position of grave doubt and guilt as a consequence of his mother's subsequent death by suicide. Annie Brady was to receive a gift from Francie who had bought a present for her in Dublin, but by the time he returns home, she had already committed suicide. The gift is described as "like a slice of a tree cut out and a rhyme carved into the wood and decorated all around the edges with green shamrocks. At the bottom was an old woman in a red shawl rocking by the fireside...I read it a good few times. A Mother's love's a blessing no matter where you roam" (41). It was to be a true "gift" for his mother, though paradoxically Francie's first gift of the narrative is never delivered.

However, Derrida shows that just like forgiveness, a gift is impossible: Francie does not "give" at all: he exchanges (for instance comics for friendship or loyalty) but for Derrida there is no gift in any sort of gift exchange. There is always merely an exchange, for the gift is "[n]ot impossible but the impossible. The very figure of the impossible. It announces itself, gives itself to be thought as the impossible." (Derrida, Given Time 7). Francis Brady consequentially follows the notion of loyalty to his mother's memory as well as an abiding loyalty to his friend Joe as a form of an "exchange." For Derrida 
there must be no reciprocity, return, exchange, countergift, or debt. If the gives me back or owes me or has to give me back what I give him or her, there will not have been a gift, whether this restitution is immediate or whether it is programmed by a complex calculation of a long-term deferral or difference. (Derrida, Given Time 12)

Hence, the gift is tainted by the obligation it transfers to the recipient. A gift must be recognized and reciprocated, thus vitiating the very possibility of a "gift." Moreover, the circle of economy or bartering cannot be broken. Within this circle of bartering, Derrida included paying oneself back psychologically:

But the one who gives it must not see it or know it either; otherwise he begins, at the threshold, as soon as he intends to give, to pay himself with a symbolic recognition, to praise himself, to approve of himself... to give back to himself symbolically the value of what he thinks he has given or what he is preparing to give... [this self-praise or self-recognition set] in motion the destruction of the gift. (14)

Thus, God's as well as Mother Mary's sacrifice, akin to Derrida's deconstructed sacrifice by Abraham, is sacred and the passion of Catholic faith which is linked to this impossible gift.

For there to be a gift event (we say event and not act), something must come about or happen, in an instant, in an instant that no doubt does not belong to the economy of time, in a time without time (17).

The immediacy described by Derrida forces the obligation immediately, rendering the ontological impossibility of the gift in time. As Hoeller states, the gift's (im)possibility offers a place outside reason and language (134). In light of Jacques Derrida's ethical philosophy of religion, the development of the narrator Francie Brady in The Butcher Boy reveals the philosophical possibility that underlies Christian revelation. Francis's religious passion for this utterly warrior-like eternal friendship with Joe becomes a truth corresponding to a military code of honor or religious faith. The image in the film adaptation of multiple appearances by Mother Mary held an enormous attraction for the guilt-ridden Francis as she warmly reassures Francie of his wish fulfilments - among others of Joe's friendship in times of Francie's doubt. In exploring Francie Brady's frequent turns to Mother Mary, Derrida offers a definition of "religious passion" in a philosophical sense:

However little may be known of religion in the singular, we do know that it is always a response and responsibility that is prescribed, not chosen freely in an act of pure and absolutely autonomous will. There is no doubt that it implies freedom, will and responsibility, but let us try to think this: will and freedom without autonomy. Whether it is a question of sacredness, sacrificiality or of faith, the other makes the law, the law is other: to give ourselves back, and up, to the other. To every other and to be utterly other. (Derrida, "Faith and Knowledge" 34)

After Joe prevents Francie from beating up Philip Nugent in the chicken coop not long after Francie's mother's death, Francie swears not be a belligerent violent attacker 
again. To ensure that this valuable friendship continues, Francie lets Philip go and passionately swears his promise to Joe: "I'm sorry Joe I said and I knew that was that. Joe was going to leave me and I'd be left with nobody no ma nothing. Francie, said Joe, you have to swear that's the end of it. I did. I swore on my life that that was the end of it and it would have been too only for Nugent" (McCabe 49). Francie thus offers his promise, an obligation, in exchange for the continuation of his friendship, not aware if this exchange will be acceptable to Joe Purcell.

"But the thing was - Joe didn't leave me" (McCabe 48). To Francie's satisfaction and relief, Joe accepts his promise and the exchange of their friendship carries on for a while further: Francie never attacks Philip again. Thus, Francie's promise is exchanged for the preservation of the "warrior" relationship. Nevertheless, Francie breaks from his obligation and visits the Nugent's pleasant, stately home, and jams his foot inside when Mrs. Nugent wants to shut the door; Francie thereby intimidates and harasses specifically Philip's mother but only when Joe is not present. The subsequent home invasion, where Francie takes it upon himself to act out the pig designation, employing a scatological expression of his status as a pig, results in the psychotic Francie becoming forcibly enrolled by police authorities at an Irish Industrial School, a correctional institution run by the Catholic Church.

After his internment at the Industrial School, Francie's friendship with Joe Purcell moved along on the basis of letter correspondence. Joe advises Francie to follow rules so that he can get out of that institution as fast as possible: "The main thing was for me to get out of this School For Pigs so we could get back into action" (72). Joe also refers to a carnival in town. In his letter, Joe describes a rifle shootout where Philip Nugent successfully shoots in the competition and wins a goldfish which he then "gives" to Joe. The exchange of the goldfish for friendship causes much apprehension for Francie who fears losing his special friendship with Joe. Such an exchange enhances Joe's obligation to Philip and in this manner binds these boys together while Francie remains distantly interned in another town:

I kept thinking about the goldfish. What did Philip Nugent think he was doing? I just couldn't believe it. He was nothing to do with us. I wished I could get the goldfish back off Joe. But what did Joe take it for? Why didn't he say: Sorry Philip you're nothing to do with us. (71)

As narrator, Francie expresses clearly his own chagrin and discomfiture: he feels he is being replaced. While a goldfish seems insignificant, Derrida stresses the nonparticularity of the "gift". The exchange event creates our relations to others, our values and our hopes. At the Industrial School among other abusive experiences, Francie engages in an exchange with the abusive Father Sullivan. Francie role-plays a little girl in a sort of negotiation which to some degree Francie dominates, for he receives Rolos in exchange. When Father Sullivan's sexual abuse is discovered, Francie once again intuits that he is in a position to bargain. In this way, Francie succeeds in getting released from this appalling Industrial School, exchanging his silence for his liberty. 
When Francie returns home from his internment, he meets up with Joe and eventually reveals the sexual abuse. Instead of expressing solidarity with his blood-brother, Joe does not believe that such a horrid act could have ever been perpetrated by a man of the cloth and leaves Francie, essentially betraying his solemn promise of eternal blood-brother friendship until death. Joe of course matures and outgrows the childish blood-brother allegiance, but Francie remains as illusionary as a child regarding its ultimate significance: Francie never grows up. On one hand Joe betrays Francie but on the other hand he could never manage to distinguish the mentally unbalanced quipster Francie from the truth-telling Francie. While there is no exchange in this interaction, Francie clearly does not pick up on the fact that Joe has become far less than his most loyal friend at this point. At the very least, compassion on Joe's part would have been expected. McCabe's narrative of exchange is brought to the brink of reason and exposes its aporia when the iconoclastic character Joe Purcell holds steadfast to the authority of the Church by denying any possibility of sexual abuse.

Benny and Annie appear not to have engaged in an exchange from the very beginning of their relationship nor throughout their marriage. When they became engaged in the town of Bundoran after World War II, Benny was an enterprising musician: he had organized a brass band, and he also read books on Irish history. He had charmed Annie with his singing.

And afterwards on the esplanade he held her in his arms and said to her are you prepared to live on potatoes and salt for the rest of your days and what did ma do she tossed back her wavy hair and laughed is that all you can offer a good-looking girl like me Benny Brady? (85)

The question Benny asks Annie certainly sounds like a lover's schmooze, i.e., that 'our love will conquer' the lack of material comfort; Annie humorously suggests that he should offer more to a girl like her. In the desperately unhappy marriage, Benny offers only his drunken obsessions of what he might have become, and expresses immense bitterness and jealousy against his brother Alo who is admired not only by the Brady family but also in the local community.

Francie confidently maintains a life of masculine competition, of fighting, warrior aggressiveness and the taking and giving of injuries, a fantasy warrior life that Joe ultimately grows out of. Francie cannot stop the cycle of exchanges, because stopping is the ultimate disruption of the meaning of his relationships. As Derrida puts it, "It is at once reason and unreason, because it also manifests that madness of the rational logos itself, that madness of the economic cycle the calculation of which is constantly reconstituted, logically, rationally (Given Time 36-37). Accordingly, Mrs. Nugent responds to Francie's aggression: she sends her toughest family relatives Devlin and Buttsy to physically attack Francie, and they truly do so in Joe's presence:

You're going to be sorry now. You're going to be sorry for what you've done, Brady. Who's going to make me sorry I says. Buttsy got all pale when I said that... Next thing 
Buttsy has the hunting knife out it was trembling away in his hand. You've had it now, Brady, said Devlin, we'll gut you like a pig... Devlin kicked me on the bad ankle. You fucking cunt, he says. When he said that I started to cry. (110)

Yet the lachrymose response by Francis is fake and he winks to Joe. Nevertheless, Joe's demeanor changes to anger just as the fight turned brutally in Francie's favor, indicating not only that the significance of their relationship had its limits, but that at this point Joe does not wish to forgive any further belligerent offences by his "blood-brother." Even though he has been attacked first, Francie's vicious response to members of the Nugent family signals the end of Joe's tolerance. He puts it into words when Buttsy asks Joe about their friendship: "I'm not hanging out with him. I used to hang around with him" (111). Again, Joe failed Francie when he really needs him, in this particular case as a loyal warrior.

The Derridian notion of the impossible gift in the novel carries forward in the next exchange. After numerous failed attempts to meet with and apologize to Joe after the brutal fight, Francie comes up with a new strategy, using Philip Nugent whom he meets and interrogates:

You gave Joe Purcell your music book, didn't you?

He said what and raised his eyebrows so I said it again. No I didn't he said. Well, I said, I'm afraid you did but all he would say then was I didn't... That's the book you gave him for I seen it in this very case there's an ass and cart on the front of it and mountains. And you gave it to Joe Purcell and now you're saying you didn't. You gave it to him didn't you? All you have to do is tell me Philip that's all I want to know. Then he sputters yes yes yes and sniffles a bit. (116-7)

The "gift" given to Joe Purcell by Philip Nugent, a music book with a donkey and a cart heading up into a green mountain scene on the cover, Emerald Gems of Ireland, like all the other gifts, is not so significant. (McCabe uses nearly the same title for a novel published eight years later: Emerald Germs of Ireland.) These performances of giving and receiving certainly weighs on Francie's mind. The act of "giving" corresponds to a relationship Philip initiates with Joe which Francie finds utterly contemptible:

I said what did you do that for? He says I just gave it to him Francie... Then it came into my head... There you are Joe said Philip handing him the book. Thank you very much said Joe. And Philip smiling away. I said to Philip: This is all to do with the goldfish isn't it? Then what does he say only: What goldfish? I don't know what you mean Francie. When I look at him saying that straight into my face, I thought: Please Philip. Don't go like your mother. (117)

Neither Joe nor Philip considers the meaning of the music book and goldfish exchanges as transgressions, and both are quite puzzled when Francie questions them. They cannot get behind the significance of Francie's axiomatic preoccupation with it since they do not perceive the logic of the exchange. Francie, however, acknowledges the significance: with Philip's goldfish and music book, some debt is to be paid back, and Joe has an obligation attached to these offerings. 
After his mother's suicide and Francie's Industrial School experience, Francie engages in an aggressive gift exchange obsession. Yet it does not consist in his own "gift-giving," but in Joe Purcell and Philip Nugent's performances of exchange. Joe Purcell betrays Francie one final crucial time after Francie travels the long distance and to find Joe's secondary school. In the evening, just past bedtime, Joe spots Francis in the dormitory and asked, "What do you want?"

I never thought Joe would ask that I never thought he would have to ask that but he did didn't he and when I heard him say it that was when I started to feel myself draining away and I couldn't stop it the more I tried the worse it got I could have floated to the ceiling like a fag paper please Joe come with me that was all I wanted to say dumb people have holes in the pit of their stomachs and that's the way I was not the dumbest person in the whole world who had no words left for anything at all. (189-190)

After the numerous failed attempts to meet Joe and present him with "gifts" Francie is prepared to give everything to Joe (134). As Tom Herron points out, "Joe refuses even to recognize Francie when he breaks into his school in the middle of the night" (177). Joe not only ends up completely abandoning Francie this time, but becomes friends with "professor face" Philip Nugent, an utterly nonwarrior-like personality whose family is clearly identified as the Brady family nemesis. Francie can only maintain his relationship with Joe through exchanges, but Joe now realizes that he is caught in an "expensive" cycle, or an exchange Joe no longer feels is worth his trouble; the exchanges in short becomes for Joe more unilateral than mutual in meaningfulness, so Joe ends the exchanges once and for all.

Joe followed this up by talking kindly to Philip Nugent on the way out, accompanying him at the dorm just as Francie is being dragged out of the school by force, signaling the final curtain for their friendship. Francie's dubitation and subsequent growing disdain through to the end of the plot, some unsuccessful attempts to exchange with Joe and the complete termination of his vital boyhood friendship are excruciating and ultimately direct Francis Brady to at first intimidate and eventually to murder Mrs. Nugent.

Francie Brady has supported the maternal presence of his otherwise mentally disturbed and battered mother. He promises to his mother in the opening of the novel that he "wouldn't let her down in a hundred million years" (5). Like Francie's loyalty to Joe, this commitment is conceived as timeless. After his mother commits suicide, Francis does not revolt against his father in his narrative. Rather, he overcompensates for "abandoning" his mother after the hostile Christmas party because of the words he heard from his nemesis: "Mrs Nugent said: I'll tell you one thing our Philip wouldn't do it. No son worth his salt would do what he did, disown his own family... No matter what they did they're still his own flesh and blood!” (McCabe 39). Regarding Francie's own father, there is no finger-pointing, no chaotic atmosphere in the new mythopoetic household that Francie creates in his unreliable narrative of order, proper living and frugal comfort. His father remarkably receives his full attention: Francie cooks, cleans and shops for the household after his father becomes acutely ill (because of chronic alcoholism). Francie 
narrates how he maintains stability to keep what little remains of his family. Even after his father dies, Francie does not abandon him. In his fantasy narrative, Francie's father and Francie together expresses their fabricated relationship: "We're going to be a happy family son. I knew we would be in the end. I said we were. I'd make sure we were, I said. It's all up to me now. Me and nobody else" (119).

Unlike the intolerant Mrs. Nugent, Francie indicates in his narrative his forgiveness toward his father, reconciling his hostile drunkenness with Francie's own absence in Dublin after the Christmas party precisely when his mother needed him the most. Thus, Francie overcompensates by becoming extraordinarily close to his father rather than making any trip or entertaining evenings for himself, and likewise thwarting Mrs. Nugent's condemnation. His intention not to let his father down goes so far that Francie remains with him in the house even after Benny had died and had turned into a rotting corpse. After being involuntarily interned at a mental institution, upon his release, he takes up his old job at the abattoir. Francie no longer has a family or friends, and he also lacks the responsibility of maintaining the cycle of exchanges with his friend Joe. As the entire devout town's population anxiously awaits the miraculous appearance of the Virgin Mary, Francie uses the tools of his trade such as his bolt gun. He goes to the Nugent home to shoot and then to monstrously butcher Mrs. Nugent like a pig, after which he is sentenced to prison for the mentally insane. Among his final words to Mrs. Nugent, he accuses her of taking Joe away from him. The Derrida notion of exchange was broken, Francie proclaims, not really by Joe but because of Mrs. Nugent's inexcusable interference. Thus, out of Francie's strange sense of a fair exchange, he murders Mrs. Nugent. Francie can be understood to engage in a kind of solipsistic nihilism in this act of vengeance. His broken exchange obsession, understood by Derrida as akin to religious passion, brings Francie beyond the edge so that Francie transforms into a homicidal psychopath.

Francie's mother's suicide, his father's inability to maintain the family, his drunkenness and subsequent death at home made Francie's friendship with Joe absolutely essential for his psychological balance and social well-being. In the end, this close companionship is all he has left of significance. I have argued that McCabe's postmodern novel suggests a direction left largely unaddressed up to now among scholars asking the most poignant question, namely why Francis Brady murdered Mrs. Nugent. Derrida's ethical writing helps to explain Francie Brady's excessive exchanges (at first sight "gift giving") as an obsession, indeed it is described as akin to religious passion by Derrida. The comic books, an analogy, goldfish, and a music book exchanged with Joe are not so significant in and of themselves, but rather the performances of giving and receiving the exchanged items weigh most of all in his obsessive mind. Through exchanges Francie preserves his very identity as Joe's best friend: the loss of Joe's friendship constitutes the loss of identity itself. Only through the cycle of exchanges with Joe can Francie maintain his sense of self. As Francie learns of the empty "gift" his father had offered to his mother, he realizes that his life was as empty as his mother's. The particular initiation ritual set up by Joe linking the two boys "forever" as blood-brothers through an exchange of blood whereby they had promised to be loyal friends to each other until they died, was no longer valid. 
Comprehending this state of affairs put Francie over the edge until he became an enraged murderer. This cause of his ultimate downfall is reiterated at the end of the film adaptation when Our Lady's final remark reminds the adult Francis not to be so obsessed: "So, don't go bothering your head about goldfish anymore, alright?" (Jordan, dir.).

\section{[Bibliography]}

Cotti-Lowell, Allison Fanous. "Narrating through Comic in Patrick McCabe's The Butcher Boy.” New Hibernia Review/Iris Éireannach Nua 17.4 (2013): 93-109.

Crockett, Clayton. Derrida after the End of Writing. New York: Fordham University Press, 2018.

Derrida, Jacques. "Faith and Knowledge: the Two Souces of 'Religion' Within the Limits of Mere Reason.” Trans. Samuel Weber. Religion. Eds. Jacques Derrida and Gianni Vattimo. Stanford, California: Stanford University Press, 1998: 1-78.

---. The Gift of Death, trans. David Wills. Chicago: University of Chicago Press, 1995.

---. Given Time: 1. Counterfeit Money, trans. Peggy Kamuf. Chicago and London: University of Chicago Press, 1992.

Eldred, Laura G. "Francis Pig vs. the Fat Green Blob from Outer Space: Horror Films and The Butcher Boy." New Hibernia Review/Iris Éireannach Nua 10.3 (2006): 53-67.

FitzSimon, Christopher. "St Macartan, Minnie the Minx and Mondo Movies: Elliptical Peregrinations Through the Subconscious of a Monaghan Writer Traumatised by Cows and the Brilliance of James Joyce." Irish University Review 28.1 (1998): 175-189.

Gauthier, Tim. "Identity, Self-Loathing and the Neocolonial Condition in Patrick McCabe's The Butcher Boy." Critique 44 (2003): 196-211.

Guidera, Anita. "Butcher Boy author McCabe haunted by death of his parents." Independent.ie 19 May 2008: n.p. https://www.independent.ie/woman/celeb-news/butcher-boy-author-mccabe-haunted-by-death-of-his-parents-26447202.html

Herron, Tom. “ContamiNation:PatrickMcCabeand Colm Tóibín's Pathographies of the Republic.” Contemporary Irish Fiction: Themes, Tropes, Theories. London: MacMillan, 2000. Hoeller, Hildegard. "Capitalism, Fiction, and the Inevitable, Impossible, Maddening Importance of the Gift” PMLA 127:1 (January 2012): 131-136.

McCabe, Patrick. The Butcher Boy. London: Picador, 1992.

Molino, Michael R. "Surveying the 'House of a Hundred Windows': Industrial Schools in Irish Writing.” New Hibernia Review/Iris Éireannach Nua 5.1 (2001): 33-52.

Smith, James M. "Remembering Ireland's Architecture of Containment: 'Telling' Stories in The Butcher Boy and States of Fear." Eire-Ireland 36.3/4 (2001): 111-130.

The Butcher Boy. Dir. Neil Jordan. DVD. Geffen Film Company, 1997.

Vránková, Kamila. Metamorphoses of the Sublime. From Ballads and Gothic Novels to Contemporary Anglo-American Children's Literature. České Budějovice: University of South Bohemia Press, 2019.

Wallace, Claire. "Running Amok: Manic Logic in Patrick McCabe’s The Butcher Boy." Irish Studies Review 6.2 (1998): 157-163. 


\section{[Address]}

University of South Bohemia

Dept. of English

College of Education

Jeronymova 10

31715 České Budějovice

CZECH REPUBLIC

koy@pf.jcu.cz

Christopher Koy teaches American and Irish literature as well as English as a Second Language at the University of South Bohemia in České Budějovice. His research interests include Jewish American and African American prose writers. He publishes mainly on intertextuality, plagiary, "Orientalism" as well as trickster figures in works by American minority writers. He recently edited an issue of Litteraria Pragensia dedicated to the novels of Philip Roth. 